Osadcha Svitlana

Doctor of Arts, Professor of the department of music history and musical ethnography of Odessa National
A. V. Nezhdanova Academy of Music
ORCID 0000-0002-0037-0787

svetikvick@gmail.com

\title{
THE SYMBOLIC PROPERTIES OF LITURGICAL SINGING TRADITION: FROM THE CATEGORY OF SYMBOL TO THE NOETIC MEASUREMENT OF CULTURE
}

The purpose of the article is to reveal the symbolic properties of the liturgical singing tradition, which allows us to trace the main parameters of the category of a symbol and to identify the noetic dimensions of culture. Research methodology assumes the use of the following general scientific methods: typological - to identify key characteristics of the liturgical singing tradition; philosophical and aesthetic, musicological analytical, historical and cultural methods. The scientific novelty of this research consists in considering the musical side of the liturgical singing tradition as the main conductor in revealing its symbolic properties. Conclusions. The canonical verbal aspect of the liturgical order, like all its verbal elements, contributes to the interaction of the external-visual and inner-auditory sides, strengthens the "rational» direction of worship, while permeating with musical-auditory emanations and acquiring some symbolic ciphering - in the case of a direct connection with the singing presentation. Thus, the religious tradition of the temple can be considered as a stable model of the "philosophical style», which in turn represents a special spiritual phenomenon that characterizes human cognitive activity and its value-semantic results. The Orthodox liturgical and singing tradition appeals to memory in its sociocultural significance and makes the phenomenon of memory leading and especially noticeable, in particular, it allows us to notice what the phenomenon of memory is related to in musical creativity. In this regard, it is especially urgent to justify the meaning of memory as a cultural universal, to define the semantic function of the notion of memory in Orthodox worship, and also to relate the phenomenon of memory to the chronotopic approach to the history of culture, with the temporal-spatial dimension of culture.

Keywords: liturgical singing tradition, symbol, canon, noosphere, noetic culture measurements.

Осадча Світлана Вікторівна доктор мистецтвознавства, профресор кафеддри історії музики та музичної етнографрії Одеської національної музичної академії ім. А. В. Нежданової

Символічні властивості літургійної співочої традиції: від категорії символу до ноетичних вимірів культури

Метою статті $€$ виявлення символічних властивостей літургійної співочої традиції, що дає змогу простежити основні параметри категорії символу та виявляти ноетичні виміри культури. Методологія дослідження передбачає використання таких загальнонаукових методів: типологічного - для виявлення ключових характеристик літургійної співочої традиції, а також фрілософрсько-естетичного, музикознавчого аналітичного, історикокультурологічного. Наукова новизна полягає у розгляді музичного аспекту літургійної співочої традиції як головного провідника у виявленні її символічних властивостей. Висновки. Канонічна словесна сторона літургійного чину та всі його вербальні елементи сприяють взаємодії зовнішньо-зорової і внутрішньо-слухової сторін, підсилює «розумову» спрямованість богослужіння, одночасно просочуючись музично-слуховими еманаціями та набуваючи деякої символічної зашифрованості - в разі безпосереднього зв'язку з співочим викладом. Отже, релігійнохрамова традиція може розглядатися як стійка модель «світоглядного стилю», що представляє, в свою чергу, особливий духовний феномен, що характеризує пізнавальну діяльність людини й її ціннісно-смислові результати. Православна богослужбово-співоча традиція апелює до пам'яті в її соціокультурної значущості та робить феномен пам'яті провідним, особливо помітним, зокрема дає змогу помітити те, з чим явище пам'яті пов'язане у музичній творчості. У зв'язку з цим особливо актуальним є обґрунтування значення пам'яті як культурної універсалії, визначення семантичної функції поняття пам'яті в православному богослужінні, а також співвіднесення явища пам'яті з хронотопічним підходом до історії культури, з темпорально-спатіальним виміром культури.

Ключові слова: літургійна співоча традиція, символ, канон, ноосфера, ноетичні виміри культури.

Осадчая Светлана Викторовна, доктор искусствоведения, профеессор кафедры истории музыки и музыкальной этнографии Одесской национальной музыкальной академии им. А. В. Неждановой

Символические свойства литургической певческой традиции: от категории символа к ноэтическим измерениям культуры

Целью статьи является выявление символических свойств литургической певческой традиции, что позволяет проследить основные параметры категории символа и выявить ноэтические измерения культуры. Методология исследования предполагает использование следующих общенаучных методов: типологического - для выявления ключевых характеристик литургической певческой традиции, а также философско-эстетического, музыковедческого аналитического, историко-культурологического. Научная новизна заключается в рассмотрении музыкальной стороны литургической певческой традиции как главного проводника в выявлении ее символических свойств. Выводы. Каноническая словесная сторона литургического чина, как и все его вербальные элементы, способствует взаимодействию внешне-зрительной и внутренне-слуховой сторон, усиливает «рассудочную» направленность богослужения, одновременно пропитываясь музыкально-слуховыми эманациями и приобретая некоторую символическую зашифрованность - в случае непосредственной связи с певческим изложением. Таким образом, религиозно храмовая традиция может рассматриваться как устойчивая модель «мировоззренческого стиля», представляющего, в свою очередь, особый духовный феномен, характеризующий познавательную

(c) Osadcha S., 2018 
деятельность человека и ее ценностно-смысловые результаты. Православная богослужебно-певческая традиция апеллирует к памяти в ее социокультурной значимости и делает феномен памяти ведущим, особенно заметным, в частности позволяет заметить то, с чем явление памяти связано в музыкальном творчестве. В связи с этим особо актуальным является обоснование значения памяти как культурной универсалии, определение семантической функции понятия памяти в православном богослужении, а также соотнесение явления памяти с хронотопическим подходом к истории культуры, с темпорально-спатиальным измерением культуры.

Ключевые слова: литургическая певческая традиция, символ, канон, ноосфера, ноэтические измерения культуры.

The relevance of the article is due to the fact that the liturgical singing cycle, as the musical side of the liturgical and singing tradition striving for certain autonomy reveals the main symbolic possibilities of the Orthodox worship and brings them to an artistically logical completion. At the same time, the official and the permanent appointment of music in the Orthodox rite is still official. Consequently, the liturgical and singing tradition, due to its appeal to the sacred and main symbols of Orthodoxy, clearly reveals the functional duality of the religious and musical genre, and also allows to answer the question of how much the concept of genre, style, style evolution is acceptable in relation to religious-ritual experience. The purpose of the article is to reveal the symbolic properties of the liturgical singing tradition, which allows us to trace the main parameters of the category of a symbol and to identify the noetic dimensions of culture.

Statement of basic materials. The Orthodox service with its special symbolism is devoted to a vast theological literature, which solves the issues related not only to the cult, but also to the questions of the general world order, human consciousness, etc. The works of leading theologians and religious philosophers open the possibility of explaining and analyzing a number of phenomena in spiritual music, thus indicating the path of convergence of musicological and theological thought, an example of which can serve as the work of the author of this article [4]. Indeed, today religious and spiritual music has become an active part of culture, firmly entered the listener consciousness of a modern man. On the other hand, the symbolic content inherent in it cannot be understood and disclosed as it deserves, outside the awareness of the subject of perception, including the musicologist, in matters of pragmatics of worship, in its statutory requirements, and finally in the history of Christianity and the Orthodox faith.

From this point of view, the range of concepts of musical culture includes ways and means of spiritual form-building, in the broad sense of the word, including canonical religious relations, as inherent features of the humanitarian system, but also as changing individualized features that are important in the context of separate historical forms of outlook and separate forms of human activity. The first ones express the integrative tendency of culture and the experience of symbolization; the last - point to the differentiating signs of creative human activity. The second ones express the style essence of culture (and the artistic forms involved); the first -contribute to the consolidation of certain structural and constitutional principles of culture as genre. The generalization of these two basic approaches to the phenomenon of musical culture opens the possibility of comparing the two historical varieties of genre systems in music - as representing the attitude to the «spiritual creativity».

The guiding force of this evolution of consciousness is the «thinking soul», a spiritual thought, including scientific and intellectual efforts as efforts to «continually increase the spiritual», which allows us to see in the human phenomenon not a natural anomaly, but an «axis of evolution of the universe» and explain the last one in relationship with the meaning of existence and the material world, and man. From the noetic point of view, the spiritual is not isolated from the material, but is a means of its completion, opening up new, yet unexplored possibilities of the material environment in its already not only terrestrial, but also the worldwide scope. Paraphrasing the Averintsev's definition of a symbol, we can say that the material becomes a spiritual force, and spiritual power gives way to new semantic possibilities of matter. At the same time, it becomes clear that all the so-called great human symbolism is of a noetic origin, and this is what allows it to initiate the development of culture as a human activity for the transformation, first of all, of the person himself [5, 81-82].

The research of A.I. Samoylenko shows the possibility of coming to the musicological approach to the study of negentropic aspects of culture and to the theory of «noospheric humanism». In her view, the history of culture, the evolution of artistic creativity from its value-semantic side, occurs as a symbolic interpretation of important, most responsible, semantic objects (carriers, conductors of meaning). The path of symbolic interpretation, thanks to the «material» side of the symbolism, becomes accessible to the noetic dimension of music [5, 89].

The value-semantic or noetic dimension of culture is formed by the person himself and is the result of the creative activity of human consciousness, therefore it cannot be imagined as a single, even very responsible, "semantic paradigm»; it is variegated, changeable, multilayered, in principle indefinable directly as well as its constituent meanings. (In addition, any semantic authority doubles, thus expressing the antinomy of human experience.) It is accessible only to indirect - «lateral» - vision, just as understanding becomes accessible only in a «reflected» form - becoming clear and fixed in knowledge. The last inevitably simplifies, restricts, but «names» what we are trying to understand, understands the boundaries of our understanding - misunderstanding and allows us to interpret the phenomena of the world from the position of these boundaries. 
In other words, the aesthetic must acquire a dialogical nature, and a concrete nature with the same necessity of bringing to artistic creativity as a specialized field of self-cogitative self-knowledge, which contributes to the creation of a special «populated», filled space of culture - the space of artifacts. Such a space, above the materially objective, has its own ideational projections - its own space of consciousness.

Meanwhile, one cannot ignore the fact that personal consciousness is integrated and exactly the consciousness ensures human integrity; the isolation of any area of consciousness as an independent one is always conditional and relative. Ideas, generated by the aesthetic need and the artistic representations caused by them, are realized as the leading symbols of culture - they allow us to find and increase symbolic values in the surrounding human «artificial» and «natural» - sociocultural and natural «worlds» $[5$, p. 150151].

Continuing the idea of $\mathrm{P}$. Florensky, it can be said that the character of perception of religious phenomena he noted, the type of religious behavior of a person, reveals the symbolic nature of the sacral. Given that the cultural activities of man, according to Florensky, are derived from the cult, it can be assumed that it is always aimed at symbolic reproduction of the surrounding world. In the broadest sense, Florensky's culture appears as a creation of reason, which breaks up into «the production of things, which meaning is not obvious, and the production of meanings, that is, the pure activity of reason, which reality, which entry into nature, is not obvious. It is necessary to prove the meaningfulness of things and the substantiation of meanings» $[7,103]$.

The symbolic foundations of liturgical activity are due to the fact that the service is carried out as Platon's «remembering», it has «something deep, something long familiar» $[8,131]$. It is older than us and our parents, older than humanity, older than the world itself; so it involves «smart doing» - the essence of intelligent prayer. The service was as if not composed, but open, found. «Orthodoxy has absorbed the very color of the world heritage and freed it from shells: we have a pure, threshed and reared, grain of religions, the very essence of humanity» $[8,131]$. It is noteworthy that the Semitic three-letter root denoting, in Russian translation, to remind, to remember, basically its meaning, is translated as «to call in the cult». Thus, the concept of remembrance turns out to be «no more than a reflex of a cult memorial, and memory in general the application to man of what is actually related to God, because He himself is remembered in the true meaning of the word» $[9,172]$.

Culture as a memory gives birth to special symbols, which are the product of the need to protect against death, overcoming the short duration of human life. Thus, $O$. Mandelstam argued that «the power of culture is in the misunderstanding of death» [6, p. 30]. Culture in its memorial and protective function becomes a means of permanently extending the life of the human race by creating special time criteria. In this connection, Lotman cites D. Likhachev's words about the formation in medieval art of such a conception of time in which «... the past was somewhere ahead, at the beginning of events, a number of which did not correspond to the perceiving subject. The «back» events were the events of the present or the future. «Back» is an inheritance that remains from the deceased; this is the last thing that connected him with us. "The front glory» is the glory of the remote past, the «first» times, «the back glory» is the glory of the last deeds» [3, 356]. Thus, time was perceived as flowing from the past to the future and changing in places these two temporal slices of culture; the past is the main value measure of cultural experience, and the memorial tendency turned towards it becomes the expression of the «deep memory» of culture, marks the eternal, timeless in the forms of collective cultural consciousness as the only form of immortality accessible to man $[6,146]$.

The very desire to remember beyond the boundaries of rational activity: this expression of the desire for non-oblivion. In order to touch once again the reality already experienced once, a certain «mystical» (Florensky), symbolic effort is necessary in order to rise above the Time. Thus, memory always exists as a transcendental phenomenon, and in it we can see the manifestation of our supra-temporal nature. Due to this we are able to perceive the past moment of Time both as a past and as now, and as now, in the present time, that is, all Time is given to us, as some «now», and looking at all Time itself stands above the Time.

The problem of memory is correlated with the chronotopic approach to the history of culture, with the temporal-spatial dimension of culture. Thus, S. Averintsev wrote that if the world of Greek philosophy and Greek poetry appears as a cosmos, that is, as a «lawful and symmetrical spatial structure», then the Christian world, the world of the Bible, is «olam» $[1,94]$. «Olam» is understood by them, on the one hand, as «antiquity», the initial pretime, on the other - as a «future». Averintsev describes «olam» as «two dark abysses of time behind and ahead of man»; this word «means» eternity, but not in the sense of motionless withdrawal from time, but in the sense of the totality and fullness of time. More precisely, it is not «eternity», but «world time», which, first, moves and, secondly, it can end and change to another «olam», another state of time and things in it» $[1,269]$. Thus, the Greek «cosmos» is located and rests in space, revealing and demonstrating its boundaries and its inherent measure, while the biblical (later Christian) «olam» is and moves in time, «rushing to the meaning passing to its limits» $[1,96]$.

Proceeding from this, «memory is a symbol-art» (P. Florensky), creation of symbols. Symbols can be placed in the past (then they are called memories), in the present (imagination) and in the future (prediction, according to Berdyaev - prophecy). But the past, the present, and the future, to be a place for symbols, must themselves be experienced simultaneously, that is, under the "corner of Eternity». In all three arrangements of symbols «the activity of thought sets forth Eternity in the language of Time; the act of this utterance is 
memory» $[9,179]$. N. Berdyaev points out that between the past, which was once real, and the present is the transforming act of memory. "Memory is a miracle in human existence, it is a transforming act of changing the past (the idealization of the past, or vice versa). In the past, there has never been what we now assert about the past. The creative act of memory brings us to the past» [2, 137]. Thus, memory is the creative beginning of thought, thought in thought. The most perfect creativity is the Divine thought, and the creativity of God is His memory. «God, while remembering, thinks, and while thinking - creates» $[9,179]$.

The question of temporality (short-time) and eternity actualizes the question of «the last problem of time - the Apocalypse» (N. Berdyaev). Apocalypse is a very mysterious text, which raises the question of the relationship between Time and Eternity. In this sense, the Apocalypse represents the paradox of awareness of time. N. Berdyaev spoke about such paradoxicality, pointing out that we cannot «get rid of the situation, that eternity will sometime come in the future» (our emphasis is SO) $[2,139]$. In the Apocalypse, the paradox of the relation to time is expressed and overcome by the words: "there will be no more time», in other words, there will be a time, when there will be no time. Consequently, the time of eternity is not subject to precise, mathematical calculus.

Thus, the concept of memory is at the intersection of central cultural concepts; the phenomenon of memory is an integral part of the movement from the meaning to its symbolic expression and from the symbol to finding its deepest meanings; it plays a leading role in the process of overcoming the culture of temporary limitedness of life. In relation to the Orthodox singing tradition, memory proves its significance as a cultural universal, becoming a semantic dominant and defining its specific ways of symbolization, therefore, incarnating in specific symbolic forms, both ritual and verbal as well as musical.

Another feature of the worship, connected to the pride of hymnography and developed after the fourth century, namely, what Schmemann calls ritual drama, and we in our work, after Florensky, call the drama of the temple action. God mess gradually takes the form of a symbolic drama with a complex system of entrances and exits, the movement of the audience, processions, etc. Accordingly, the temple in which this drama is performed and set also grows verbal symbolism. In Simeon of Thessalonica, one can find detailed explanations of the symbolism of incense and literally every movement of servants and prayers.

Conclusions. The canonical verbal aspect of the liturgical order, like all its verbal elements, contributes to the interaction of the external-visual and inner-auditory sides, strengthens the "rational» direction of worship, while permeating with musical-auditory emanations and acquiring some symbolic ciphering - in the case of a direct connection with the singing presentation. Thus, the religious tradition of the temple can be considered as a stable model of the "philosophical style», which in turn represents a special spiritual phenomenon that characterizes human cognitive activity and its value-semantic results.

The temple tradition, converted to the sacred religious meanings, appeals to the highest possible methods of measuring spirituality, suggesting a road to the so-called «unpredictable», anagoric sense, or rather, proving the primary meaning of this form of meaning, beyond verbal rationalization.

Ritual order is a symbolic action, carrying in itself a regular religious symbolism. In this respect, the prayer-level level of the liturgical text explains the symbolic nature of the ritual action, creates a kind of commentary on it, points to the moments of movement and stopping in a worship, to its internal drama, and also to the processes taking place in the consciousness of the person, who is present at the worship.

The liturgical word creates its own symbolic series that is requiring special conditions of understanding. It can be considered sufficiently recognized that the word in the Orthodox rite is the focus, the central semantic element of the liturgical text. However, being sounded in its basis, the Orthodox prayer-text requires the completion and expression in its musical side. It is the manner of musical reading (readingsinging) of a musical text that is the most vivid identification mark of it as a cult, religious one. If it is read differently, it ceases to be so. The singing of the prayerful (liturgical) text forms the third, final, and, at the same time, forming level of the musical text, and, what is especially important, this level has already been judged from the point of view of its emotional-expressive function, according to its psychological significance, and this meant that already from the early Christian times, a sufficiently independent meaning, a symbolic expression, was assigned.

The Orthodox liturgical and singing tradition appeals to memory in its sociocultural significance and makes the phenomenon of memory leading and especially noticeable. In particular, it allows us to notice what the phenomenon of memory is related to in musical creativity. In this regard, it is especially urgent to justify the meaning of memory as a cultural universal, to define the semantic function of the notion of memory in Orthodox worship, and also to relate the phenomenon of memory to the chronotopic approach to the history of culture, with the temporal-spatial dimension of culture.

\section{תimepamypa}

1. Аверинцев С. Поэтика ранневизантийской литературы. Санкт-Петербург : Азбука-классика, 2004. 480

c.

2. Бердяев Н. Вечность и время // Вестник РХД. Париж - Нью-Йорк - Москва, 1998. С. 135-140.

3. Лотман Ю. Внутри мыслящих миров. Семиосфера. Санкт-Петербург : Искусство-СПБ, 2001. С. 150-

392.

4. Осадчая С. Теоретические аспекты изучения православной певческой традиции: история и современность : [монография]. Одесса : Астропринт, 2012. 264 с. 
5. Самойленко А. Диалог как музыкально-культурологический феномен: методологические аспекты современного музыкознания: дис. ... доктора искусствоведения. 17.00.03. Одесса, 2003. 437 с.

6. Самойленко А. Музыковедение и методология гуманитарного знания. Проблема диалога: Монография. Одесса : Астропринт, 2002. 244 с.

7. Флоренский П. Из богословского наследия // Богословские труды. Москва, 1972. Вып. 9. С. 85-248.

8. Флоренский П. Философия культа. Москва : Мысль, 2004. 685 с.

9. Флоренский П., свящ. Стоп и утверждение истины: Опыт православной теодицеи. Москва : ООО Издательство АСТ, 2003. 640 с.

\title{
References
}

1. Averintsev, S. (2004) The poetics of early Byzantine literature. S.-P. : Classical alphabet [in Russian].

2. Berdyaev, N. (1998) Eternity and time. Bulletin of the RHD. Paris -New York - Moscow [in Russian].

3. Lotman, Yu. (2001) Inside the thinking worlds. The Semiosphere. S.-Pb.: Art-SPB [in Russian].

4. Osadchaya, S. (2012) Theoretical aspects of studying the Orthodox singing tradition: history and modernity: [monograph]. Odessa: Astroprint [in Russian].

5. Samoylenko, A. (2003) Dialogue as a musical and cultural phenomenon: the methodological aspects of modern musicology. Doctor's thesis. Odessa. [in Russian].

6. Samoylenko, A. (2002) Musicology and methodology of humanitarian knowledge. The problem of dialogue: Monograph. Odessa: Astroprint [in Russian].

7. Florensky, P. (1972) From the theological heritage. Theological works. Moscow, 9 [in Russian].

8. Florensky, P. (2004) Philosophy of the cult. Moscow : Thought [in Russian].

9. Florensky, P. (2003) Stop and the affirmation of the truth: The experience of Orthodox theodicy. Moscow: OOO AST Publishing House [in Russian].

Стаття надійшла до редакції 28.08.2018 p.

Удк $378.011 .3-051: 7$

\author{
Savchenko Regina \\ doctor of pedagogical sciences, professor, \\ professor of the department of theory \\ and methodology of music education, choral singing and \\ conducting of the \\ National Pedagogical University behalf of M.P. Dragomanova \\ ORCID 000243808777 \\ sarina_30@ukr.net
}

\section{CULTURALITY OF MUSIC-PEDAGOGICAL TRAINING OF FUTURE SPECIALISTS ARTISTIC EDUCATION}

Objective. Substantiation of expediency of realization of the cultural approach in musical and pedagogical preparation of the future experts of art education. The methodology of the research consists in the study of the culturological approach in relation to the musical and pedagogical preparation of students - future specialists in the field of art education. This methodological approach allows us to disclose and analyze certain aspects and components of vocational training of future music teachers in social relations, to find a dynamic view of the future of man, new dimensions of his self-realization. Scientific novelty of the work is to expand the understanding of the possibilities of culturological impact in the musical and pedagogical preparation of students: an awareness of the potential of the culturological approach in the educational process; enriching the cultural space of students; the realization of the principle of cultural appropriateness as a sign of artistic education; as means of formation and development of student culture: universal, pedagogical, artistic. Conclusions. The culturological approach provides a methodological basis for the professional training of future specialists in art education, namely: on the affirmation of universal human values, value-semantic accents of activity; the fundamental provisions of normative documents concerning the cultural appropriateness of musical and pedagogical activity, the unity of universal and national, public and personal, theoretical and practical, education and upbringing.

Keywords: culturological approach, musical and pedagogical training, future specialists of art education.

Савченко Регіна Анатоліївна, доктор педагогічних наук, профессор, профресор кафедри теорії та методики музичної освіти, хорового співу і диригування Національного педагогічного університету імені М. П. Драгоманова

Культуровідповідність музично-педагогічної підготовки майбутніх фахівців мистецької освіти

Мета роботи. Обгрунтування доцільності реалізації культурологічного підходу в музично-педагогічної підготовки майбутніх фахівців художньої освіти. Методологія дослідження полягає в дослідженні культурологічного підходу стосовно музично-педагогічної підготовки студентів - майбутніх фрахівців в галузі мистецької освіти. Зазначений методологічний підхід дозволяє розкрити і піддати аналізу певні аспекти і компоненти професійної підготовки майбутніх педагогів-музикантів у соціальних відносинах, знайти динамічний погляд на майбутнє людини, нові виміри його самореалізації. Наукова новизна роботи полягає в розширенні уявлень про можливості культурологічного впливу в музично-педагогічної підготовки студентів: усвідомленням потенціалу культурологічного під-

(c) Savchenko R., 2018 